\title{
AL KHAWARIJ DAN AL MURJIAH SEJARAH DAN POKOK AJARANNYA
}

\section{Syandri}

Sekolah Tinggi Ilmu Islam dan Bahasa Arab (STIBA) Makassar, Jl. Inspeksi PAM Manggala-Antang Makassar E-Mail : syandri@stiba.ac.id

\begin{tabular}{ll} 
Keywords : & \multicolumn{1}{c}{ ABSTRACT } \\
\cline { 2 - 3 } ideology, khawärij, murjiah & The emergence of diverse schools in Islam began with the assassination \\
& of Usंman bin Affan. These groups were basically one of the decline \\
& causes in the Moslem, and the first emerging group among all other \\
& groups was Khawarij, a group with Takfir ideology that is to accuse \\
& great sinner of apostasy. This ideology is indeed an extreme one. \\
& However, another contradicted extreme group appeared that is known \\
& as Murji'ah with its doctrine believing that the sins will not give any \\
& influence towards the faith of a Moslem. Therefore, this study will \\
& illustrate the origins and the doctrines of both extreme groups, and \\
& among the results, it can be inferred that these groups continuously \\
& experienced internal conflicts since their early emergence during the \\
& reign of caliph Usंman bin Affan until the formation of various sects \\
& of each groups.
\end{tabular}




\section{PENDAHULUAN}

Islam pada awal mula perjalannya belum menghadapi begitu banyak masalah internal, kalaupun kita menemukan berbagai penghalang, maka kebanyakannya merupakan sebab-sebab external, hal ini nampak sampai pemerintahan Umar bin Khattāb.

Akan tetapi bersamaan dengan berjalannya waktu, semakin luasnya wilayah kaum Muslimin, dan semakin banyaknya masalah yang timbul di tengah-tengah kaum Muslimin, hal ini pun menyebabkan munculannya beberapa kelompok, yang masingmasing menganggap kelompoknya yang paling benar.

Terlebih lagi setelah terjadinya pembunuhan Uśman bin Affān, dan perselisihan antara pasukan yang dipimpin oleh Alī bin Abī Țālib, dari sinilah muncul sebuah kelompok yang disebut dengan Khawarij, yang memiliki keyakinan bahwa para pelaku dosa besar adalah kafir, dan menghukumi mereka akan kekal dineraka.

Kemudian muncul lagi kelompok yang pada awalnya hanya berlepas diri dari pertikaan antara Muāwiyah dan Alī, yang kemudian selanjutnya terjatuh pada kesalahan yang sangat fatal, yang sebenarnya adalah upaya mereka menandingi Khawārij.

Mereka ini adalah Murjiah, yang pada dasarnya memiliki keyakinan bahwasanya sekali seorang Muslim mengikrarkan syahadat, maka keimanannya akan tetap selamalamanya, walaupun dia melakukan kemaksiatan dan melanggar perintah

${ }^{1}$ Muhammad bin Muhammad bin Abdurrazak Al Husaini Abu Al Faid, Tāj Al Arūs Min
Allah. Oleh karena itu sangat penting untuk melihat perkembangan dari setiap kelompok-kelompok ini.

Berdasarkan pendahuluan diatas, maka penulis membatsi pembahasan dalam jurnal ini pada beberapa poin berikut:

1. Bagaimanakah awal mula munculnya $\mathrm{Al}$ Khawārij?

2. Bagaimana pokok ajaran $\mathrm{Al}$ Khawārij?

3. Bagaimana asal muasal munculnya Al Murjiah?

4. Bagaimanakah Pokok ajaran $\mathrm{Al}$ Murjiah?

\section{PEMBAHASAN}

\section{Al Khawārij}

a. Definisi Al Khawārij.

Al Khawarij secara etimologis berasal dari kata tunggal "Khärij" dan Khärïi di salur dari kata $A l$ Khärij yang kesemuanya memiliki makna yang sama yaitu diluar atau bagian luar.

Oleh karena itu para spesialis (ulama) bahasa menyandarkan pengertian mereka secara bahasa akan kelompok ini dengan kata (kharaja) hal ini disebabkan karena mereka telah keluar dari (prinsip) agama dan keluarnya mereka dari ketaatan kepada Imam Ali. ${ }^{1}$

Menurut terminologi para ulama berbeda pendapat dalam memberikan definisi tentang $\mathrm{Al}$ Khawārij, diantaranya:

1. Diantara ulama ada yang memberikan definisi dengan mengambil pengertian politik secara umum, yaitu setiap yang keluar dari pemimpin yang sah secara syari di setiap zaman.

Jawāhir Al Qamūs, Vol. V (t.Cet; Dar Al Hidayah. t.t). h. 452. 
Al Syaristānī mengatakan bahwa Al Khawārij adalah setiap orang yang keluar dan memisahkan diri dari pemimpin yang telah disepakati kepemimpinannya, apakah itu yang keluar dari kepemimpinan Khulafä' Ar Rasyidīn, kepemimpinan tabī’in, dan kepemimpinan yang ada di setiap zaman. $^{2}$

Diantara ulama ada yang mengkhususkan Al Khawārij hanyalah kelompok yang memisahkan diri dan keluar dari kepemimpinan Alī.

Al Asy'arī mengatakan: mereka dikatakan sebagai Khawārij Karena mereka telah keluar dari kepemimpinan Ali. Ibnu Hazm menambahkan senada dengan perkataaan Al Syirastānī bahwasanya kata $A l$ Khariji disandarkan kepada setiap yang secara pemikiran menyerupai kelompok yang keluar dari kepemimpinan Alī kapan pun dan dimana pun mereka berada. ${ }^{3}$

2. Adapun Ulama "Ibädìah" mengatakan bahwa Khawārij adalah kelompok yang muncul di zaman tābỉin dan tabi’ al tābî̀in.

\section{Khawārij}

b. Sejarah Kemunculan

Ahli sejarah dan ulama firaq berbeda pendapat kapan awal mula munculnya kelompok Khawārij, di antaranya:

1. Khawārij muncul di zaman Rasulullah

Diantara ulama yang mengambil pendapat ini adalah $\mathrm{Al}$ Syiristānī, Ibnu Hazm, Ibnu Al Jauzi, dan Al Ajirī, berdalilkan sebuah hadis yang diriwayatkan oleh Iman $\mathrm{Al}$ Bukhārī dan Muslim.

${ }^{2}$ Abu Al Fath Muhammad Abdul Karim Abi Bakar Ahmad Al Syiristānī, Al Milal wa Al Nihal, Vol. I (Muassasah Al Halabī wa Al Syarikah li Al Nasyr wa Al Tauzī', 1378H-1968M). h.114.
Para Ulama mengatakatan bahwa tokoh Khawārij yang paling pertama adalah Dzul Khuwaishirah, yang menentang kebijakan Rasulullah dalam pembagian emas yang dibawa Alī dari perang Yaman. Diriwayatkan dari Abu Said Al Khudri, ia bercerita:

Alī bin Abī Tāalib menyerahkan emas dari Yaman kepada Rasulullah dalam kantong kulit yang disamak dengan Qaraz, yang tidak dapat diperoleh dari tanahnya.

Kemudian Rasulullah membagi-baginya diantara empat orang yaitu Uyainah bin Hishn, Al Aqra' bin Habs, Zaid Al Khail, dan yang keempat Alqamad bin Alatsah atau Amir bin Al TTufail. Melihat ini, salah seorang yang hadir mengajukan protes dengan berkata,"Kami lebih berhak atas emas itu daripada mereka."

Selanjutnya protes ini disampaikan kepada Rasulullah. Beliau pun bersabda,"Tidaklah kalian memercayaiku padabal aku adalab orang kepercayaan penduduk langit yang menyampaikan kebar langit lepadaku pagi dan petang?"

Lantas seorang laki-laki bermata cekung, berpipi memerah, berkening tinggu, berjenggot tebal, berkepada plontos, dan berkain sarung terlipat berkata," wahai Rasulullah, bertakwalah kepada Allah!" Rasulullah pun bersabda," Celakalah engkau, bukankah aku penduduk bumi yang paling pantas untuk bertakwa kepada Allah?"

Lalu lelaki itu pergi. Khālid bin Walīd angkat bicara, "Wahai rasulullah, bolehkah aku memenggal lehernya?" Rasulullah menjawab," Jangan, barangkali ia masib solat," Khalid

\footnotetext{
${ }^{3}$ Gālib bin Alī A'wajī, Firaq Mua'sirah, Vol. I (Cet. VII; Jeddah: Dar Al A'sriyah, $1430 \mathrm{H} / 2009$ M), h. 228.
} 
menukas," betapa benyaknya orang solat yang mengucapkan dengan mulutnya apa yang tidak dalam hatinya," Rasulullah bersabda," Aku tidak diperintabkan untuk mengorek isi hati menusia ataupun membelah dada mereka.

Beliau memandang lelaki yang sedang pergi itu, dan bersabda," Dari sumber lelaki itu akan keluar sekelompok irang yang membaca kitabullah dengan kering: tidak sampai melewati tenggorokan mereka. Mereka keluar dari agama sebagaimana anak panab keluar dari tubub bintang yang dipanah."

Aku yakin beliau berdabda," kalaulah aku mendapati mereka (selagi aku masib hidup), niscaya kutumpas mereka seperti tertumpasnya kaum $\dot{\text { Samüd. }}{ }^{4}$

2. Khawārij muncul di zaman Uṡmān bin Affān.

Diantara ulama yang berpendapat demikian adalah Ibnu Katsīr, dan Ibn Abī Al I'zz, yang mereka maksudkan adalah mereka yang melakukan protes yang berujung pada pembunuhan Khalifah Uṡmān bin Affān.

3. Khawārij muncul awal kalinya di masa Alī bin Abī Țālib, ketika Țalhạ dan Al Zubair keluar dari pemerintahan Alī, hal ini sebagaimana disebutkan oleh ulama kelompok Ibädiah, akan tetapi perkataan ini tidak bisa dijadikan sandaran, karena mereka tidak sama sekali memiliki sifat sebagaimana sifat kelompok khawārij, terlebih lagi mereka adalah diantara para sahabat yang dijamin oleh Rasulullah dengan syurga.

${ }^{4}$ Ali Muhammad Al Syalabī, Khawārij dan Syīah dalam Timbangan Ahlu Sunnah wal Jamāah, ( Cet. I; Jakarta Timur: 2012). h. 14-15

${ }^{5}$ Galib bin Ali A'waji, Firaq Mua'sirah, Vol. I, h. 233.
4. Kelompok yang keluar dari pasukan $A \bar{i}$, dan inilah pendapat yang paling benar. ${ }^{5}$

5. Mereka adalah kelompok yang muncul di masa Nāfi' bin Azraq pada tahun $64 \mathrm{H}$. pendapat ini juga pendapat yang lemah, karena hanya di sandarkan pada kelompok Ibadiah yang mereka sendiri berbeda pendapat.

Setelah melihat sejarah perkembangan dan berbagai difinisi yang disebutkan oleh para ulama, maka dapat di simpulkan bahwa kelompok Khawarij adalah kelompok yang beraliran politik, memiliki keyakinan khas berbeda dengan keyakinan kaum Muslimin secara umun, dan kelompok yang keluar dari pasukan Alī .

Galib bin Ali A'waji dalam bukunya menuliskan sejarah kemunculan Khawarij: Setelah terpilihnya Alì sebagai khalifah pengganti Uṡman bin Affān yang terbunuh, Muawiyah sebagai gubernur Syām ketika itu, meminta kepada Alī untuk menangkap dan menghukum pembunuh Alī, jika Alī tidak melakukannya maka Muawiyah tidak akan berbaiat kepada Alī. Adapun Alī ketika itu berpendapat bahwa yang paling penting dilakukan sekarang adalah menstabilkan kondisi yang begitu kacau, barulah kemudian memproses para pelaku pembunuhan Uśmān.

Terlebih lagi orang-orang yang telah bersekongkol pada pembunuhan Uśman bukan jumlah yang sedikit, bahkan memiliki kekuatan yang begitu besar, jika saja mereka diproses sekrang

Glbnu Hazm Al Z̄āhirī Al Andalusī, Al Fasl fi Al Milal wa Al Ahwā wa Al Nihal, Vol. IV (Cet. I; Maktabah Muhammad Alī Sobih wa Auladuhu, 1347 H). h. 157. 
maka yang akan terjadi adalah fitnah yang begitu besar.

Lebih dari itu proses pencarian, siapakah pembunuh sebenarnya dari Utsman membutuhkan waktu yang cukup lama, sebelum diputuskan hukum syariat atasnya, akan tetapi Muawiyah tidak bisa sabar menunggu semuanya.

Maka sebagai hasil dari ketidak sepakatan ini, terjadilah perang yang di kenal dengan perang șiffin, dimana Muawiyah sebagai panglima pasukan dari Syam sementara Ali sebagai panglima pasukan dari Irāq.

Pada saat pertempuran begitu sengitnya, dan mampak kelemahan dari pihak Muawiyah, beliau bermusyawarah dengan Amr bi Al Ash apa yang harus mereka lakukan, maka mereka bersepakat untuk mengangkat al Quran di setiap ujung tombak mereka, sekitar 500 melakukan hal tersebut, dan meminta kepada pihak Alī untuk melakukan Tahkim, sebagai jalan keluar akan permasalahan yang mereka hadapi ,maka Ali dan pasukannya pun sepakat menerima usulan Muawiyah.

Maka keluarlah dari jamaah Aīi kelompok yang tidak menyetujui tahkim, yang kemudian hari menjadi cikal bakal Khawārij sebagai sebuah jamaah. $^{7}$

\section{keyakinan Khawarij}

\section{c. Julukan Bagi pengangut}

\section{Al Muhakkimah}

Disebut golongan $\mathrm{Al}$ Muhakkimah. Bagi mereka Alī, Mua'wiyah, kedua pengantara peristiwa tahkīm Amr Ibn Al Ash dan Abu Mūsa I, h. 39.

${ }^{7}$ Galib bin Ali A'waji, Firaq Mua'sirah, Vol.

${ }^{8}$ Harun Nasution, Teologi Islam Aliran Aliran Sejarah Analisa perbandingan (Cet. V; UI Press, 2013). h. 15.
Al Asya'rī dan semua orang yang menyetujui arbitrase (Tahkiīm) bersalah dan menajdi kafir. ${ }^{8}$

\section{Al Harūriyah}

Mereka adalah kelompok yang memerangi Alī dan para sahabat yang lain, mereka bertempat tinggi di sebuah wilayah di Irāk yang di sebut Harūra.

\section{Ahlu Nahrawān}

Nama ini adalah nama tempat dimana Alī memerengi mereka, oleh karena itu, nama ini pun disandarkan kepada kelompok ini.

\section{Al Syirāh}

Mereka mengatakan bahwa mereka adalah kelompok pilihan Allah dengan memerengai kaum Muslimin.

\section{Al Māriqah}

Rasulullah yang telah memberikan julukan ini kepada penghulu dan asal muasal munculnya kelompok ini.

\section{Al Mukaffirah}

Salah satu keyakinan kelompok ini adalah mengkafirkan setiap pelaku dosa besar.

\section{Al Sabaiah}

Karena mereka adalah kelompok yang muncul disebabkan oleh Ibn saba' al Yahudi.

\section{Al Nāsibah}

Julukan ini di sandarakan kepada mereka, karena telah menyandarkan kebencian kepada Alī dan keluarganya.

\section{doktrinnya}

d. Sekte-sekte khawārij dan

\section{Al Zāriqah}

Mereka adalah pengikut Nafi' bin Al Azraq yang muncul pada masa kepemimpinan Abdullah bin Zubair.

${ }^{9}$ Nasruddin Abdul Karim Al Aql, Al Khawārij, (Cet. I; Riyadh, 1419H/1998M). h. 2223. 
Diantara doktrin mereka:

a) Mengkafirkan Uśmān dan

Alī.

b) Menghukumi pelaku dosa besar sebagai orang kafir dan menghukumi mereka kekal dalam nereka.

c) Mengkafirkan siapa saja yang menyelisihi pendapat dan tidak berhijrah kewilayah mereka.

d) Menghukumi setiap negara yang menyelisihi mereka adalah adalah Negara kafir.

e) Menghapus hukum $\mathrm{Al}$ rajam dan al Qadz

\section{Al Najdāt}

Mereka adalah pengikut Najdah A'mir Al Hanafí, merupakan pecahan dari kelompok Nafi', yang mencoba untuk meringankan sebagian pendapat kelompok Nafi' yang begitu extrim.

Diantara doktrin mereka:

a) Mengkafrikan golongan yang berselisih dengan mereka, termaksud $\mathrm{Al}$ Zariqah, kecuali yang tidak berilmu diantara mereka, mereka semua diberikan penangguhan hukum kafir sampai setelah dakwah sampai kepada mereka.

b) Menghukumi negara atau wilayah yang tidak sepaham dengan bereka sebagai negara yang fasik bukan kafir.

c) Membela para pelaku kesalahan dengan syarat sepemahaman dengan mereka, akan tetapi mereka tetap kekal dalam neraka.

d) Mukmin adalah mereka yang berpemahaman dengan pemahaman mereka, mereka tidak mengkafirkan hanya karena melakukan pelaku dosa besar, keculai mereka yang menampakkan maksiat dan kesalahannya.

\section{Al Ibadiah}

Mereka adalah pengikut Abdullah bin Iyadh at Tamìmi, yang merupakan pecahan dari kelompok Nafi' dan sangat memuliakan Jābir bin Zaid Ahmad seorang tabi'in, oleh karena itu kelompok ini disandarkan ke beliau.

Al Ibadiah adalah salah satu kelompok Khawārij yang masih tersisa sampai saat sekarang ini.

Doktrin Al Ibadiah:

a) Mengingkari sifat Allah, kelompok ini juga mengikuti kelompok Al Mu'tazilah makhluk.

b) Meyakini Al Quran adalah

c) Meyakini bahwa pelaku dosa besar akan kekal di nereka, tanpa menghukumi mereka sebagai kufur akbar.

d) Mengkafirkan orang-orang yang berpendapat Allah di akhirat kelak bisa di lihat dengan mata adalah kafir. Al Quran. ${ }^{10}$

e) Melakukan ta'wil terhadap

\section{Al Sufariyah}

d. berubahnya Khawārij menjadi kelompok kalamiah

Setelah munculnmya kelompok-kelompok kalamiah (Al Jahmiah, Al Mu'tazilah, Al Asyairah dan Maturidiyah) disinilah awal mula Khawārij terpengaruh dengan ilmu kalam:

Al Asy'ari (wafat $324 \quad \mathrm{H}$ ) memaparkan dalam salahn satu tulisannya, perubahan tersebut, diantaranya:

1. Pendapat mereka pada permasalahan Tauhid: Al Asya'ri

10Safar bin Abdul Rahmān Al Hawālī, Usul al Firaq wa Al adyān wa Al Mażāhib Al Fikriyyah, (t. cet; Riyāḍ, 1431H/2010M). h. 30-31. 
mengatakan (Adapun para permasalahan tauhid pendapat Khawārij mengikuti pendapat Mu'tazila) kemudian ia mengatakan: (Adapun Ibadiah, menyelisihi Mu'tazilah pada permasalahan tauhid hanya pada permasalah Al irädah (kemauan).

2. Pendapat Khawārij terhadap Al Quran: Seluruh kelompok Khawārij mengatakan bahwa Al Quran adalah makhluk.

3. Pendapat Khawārij pada permasalahan Al Qadr: kelompok ini terpecah dan berbeda pendapat pada masalah Qadr, sebahagian mengikuti pendapat Mu'tazilah dan sebahagian yang lain berpendapat iśbät.

4. Pendapat Khawārij pada permasalahan al Waìd: Khawārij berpendapat sebagaimana pendapat Mu'tazilah akan tetapi Khawārij mengatakan: para pelaku dosa besar akan di siksa pada hari kiamat sebagaimana siksaan orang orang kafir, adapun Mu'tazillah mengatakan para pelaku dosa besar tidak akan di siksa dengan siksaan orang kafir.

5. Pendapat Khawārij dalam hal mengangkat senjata untuk memerangi kaum Muslimin: Seluruh kelompok Khawārij mengatakan bolehnya mengangkat senjata untuk memerangi kaum Muslimin, kecuali kelompok Ibadiah yang mengatakan tidak demikian, akan tetapi mereka berpendapat untuk menurunkan dan memberontak kepada pemimpin yang tidak adil.

${ }^{11}$ Nasruddīn Abdul Karīm Al Aql, Al Khawārij, h. 39-40.

12Ibnu Manżūr, Lisān Al Arab, Vol XIV, (Cet. I; Bairūt: Dār Al S̄ādirūn, t.t). h.82.
6. Pendapat Khawārij terhadap para khalifah dan sahabat Rasulullah, seluruh kelompok Khawārij mengakui keabsahan kepemimpinan Abū Bakar dan Umar dan menolak kepemimpinan Uśmān bin Affān, mereka menerima kempemimpinan Alī sebelum arbitrase adapun setelahnya mereka menolak kepemimpinan $\mathrm{Al} \overline{1}$, mereka bahwan mengkafirkan Mu'awiyah, Amr bi Al Ash, Abū Mūsa Al Asy'ari, akan tetapi mereka tetap yakin bahwa kepemimpinan hanyalah milik Quraish.

Al Saksaki mengatakan dalam Al Burban: Kelompok Khawārij telah mengikuti Mu'tazilah kecuali pada permasalah irädah, ini menunjukkan perubahan yang drastis kelompok ini, yang awalnya hanya membahas masalah Aqidah (permasalahan hukum) kemudian berubah mengikuti Mu'tazilah. ${ }^{11}$

\section{Al Murjiah}

\section{A. Definisi Murjiah}

1. Secara etimologi berasal dari kata Alirjā yang berarti mengakhirkan ${ }^{12}$ sebagaimana disebutkan Ka'ab bin Malik meceritakan kisah taubatnya:

$$
\text { "أرجأ رسول الله أمرنا" }
$$

Artinya: "Rasulullah Arja' (mengakhirkan) permasalahan kami". ${ }^{13}$

Dan diantara ulama ada yang mengatakan bahwa Al Murjiah di ambil dari kata Irja yang berarti penundaan atau agan-agan. ${ }^{14}$

2. Murjiah secara terminology berarti kelompok dalam Islam yang berkeyakinan bahwa kemaksiatan tidak akan mempengaruhi keimanan seorang

\footnotetext{
${ }^{13}$ Majid Al Zāmil dan Mun'im Abdul Arahmān, Al Murjiah Nasyatuha wa Mu'taqadātuha, (t. cet; t.t). h.4.

${ }^{14} \mathrm{Al}$ hāfiż ibnu Kasīir, Tafsìr Al Qurān Al Ažìm, Vol. II, (Cet. I; Bairūt: Dār al Khaer, 1410 H). h. 264.
} 
Muslim, sebagaimana kekafiran tidak akan mempengaruhi ketaatan. ${ }^{15}$

Ibnu Taimiyyah menukil perkataan Imam Ahmad mengenai Murjiah bahwasanya mereka adalah kelompok yang mengatakan amalan (ibadah) bukan bagian dari keimanan. ${ }^{16}$

\section{Murjiah}

\section{B. Sejarah Munculnya}

Kelompok ini muncul pertama kali pada masa sahabat yaitu di akhir pemerintahan Uṡmān bin Affān, setelah tersebarnya berita akan adanya sebagian kelompok yang ingin menurunkan dari tampuk kepemimpinan, dan munculnya fitnah, yang menyebabkan terbunuhnya Uṡmān, sebagian sahabat Rasulullah menarik diri dari pertikaan yang terjadi dengan berdalilkan sebuah hadits yang diriwayatkan dari Abu Bakar dimana Rasulullah bersada:

"Akan terjadi hurubara (fitnah) dimana ketika itu orang yang duduk. lebih baik dari pada yang berjalan, yang berjalan lebih baik dari yang berlari lari kecil (ikut dalam kekacauan). Jika saja kalian mendapati zaman tersebut, maka barangsiapa yang memiliki onta maka sebaiknya dia mengembala ontanya, barangsiapa yang memiliki kambing hendaknya dia mengembalakan kambingnya, dan barangsiapa yang memiliki sebidang tanah maka hendaknya dia menggarap tanahnya, "Kemudian salah seorang sahabat bertanya." Wahai Rasulullab! Bagaimana pendapat anda bagi orang yang tidak. memiliki onta, kambing, dan sebidang tanab? "beliau menjawab," bendaknya dia

15Ibnu Manẓūr, Lisān Al Arab, Vol XIV, h.83.

${ }^{16}$ Ahmad Ibnu Taimiyyah, Majmū' fatawa, Vol. XIII (t.Cet; Madīnah Al Munawwarah: Majma' Malik Fahad Li Al Ṭibāah Mushaf Al Syarīf, 1425H/2009M). h. 85. mengambil pedangnya dan memukulkannya ke sebuah batu, kemudian mencari tempat yang lebih baik umtuknya.

Kumpulan sahabat inilah yang tidak ikut dalam pertikaian yang terjadi antara Muawiyah dan Alī, mereka tidak bisa menentukan (mengakhirkan) siapa diantara kedua kelompok ini yang paling benar. ${ }^{17}$

Ini adalah teori pertama yang di kembangkan oleh sebagian sahabat dengan tujuan menjamin persatuan dan kesatuan ummat ketika terjadi pertikaian. ${ }^{18}$

Kalau kita melihat kepada kumpulan sahabat yang tidak ikut pada perselisihan, maka mereka masuk dalam katagori irja' dari sisi bahasa. Pastinya apa yang dilakukan ini adalah hal yang baik dalam rangka persatuan.

Akan tetapi ketika perpecahan dan perselisihan semakin membesar, ditambah lagi dengan Khawārij yang mengkafirkan dengan sangat mudahnya, maka kaum Murjiah datang sebagai tandingan yang pada awalnya memiliki teori yang sangat bagus yaitu menangguhkan hukum pelaku dosa besar hanya kepada Allah.

Bersama dengan berlalunya waktu, maka datanglah generasi yang jauh dari konsep awal yang mengatakan bahwa:"Kemaksiatan tidak akan mempengaruhi keimanan seseorang.

Bagi mereka keimanan hanyalah pengucapan, meyakini dan mengetahui, yang ketika seorang melakukan maksiat setelah itu, maka keimanan mereka tidak akan terganggu,

\footnotetext{
${ }^{17}$ Muhammad Abu Zahrah, Tarīkh Al Mazāhib Al Islāmiayah fi Al Siasyah wa Al Aqāid wa Tārikh al Mazāhib Al Fiqhiyah, (t.Cet; Mesir: Dār Al Fikr Al Arabi, t.t). h.113.

${ }^{18}$ Abdul Razak dan Rosihon Anwar, IImu Kalam, (Cet. IV; Bandung: Cv Pustaka Setia, 2015). h.71.
} 
karena keimanan itu terpisah dari amal ibadah.

Bahkan sebahagian Murjiah aliran keras mengatakan bahwasanya keimanan itu hanya percaya didalam hati, seorang akan tetap beriman walaupun mereka meninggal setelah mengucapkan kalimat kekufuran, menyembah berhala, membantu kaum Yahudi dan Nasrani dalam memusuhi kaum Muslimin, beriman kepada trinitas. ${ }^{19}$

Adapun Ibnu Taimiyyah mengatakan salah satu perselisihan yang paling pertama terjadi di kalangan kaum Muslimin adalah permasalahan Iman, yang mengakibatkan perseteruan sampai pada taraf saling mengkafirkan.

Khawarij adalah kelompok pertama yang terjatuh dimana mereka mengkafirkan kaum Muslimin yang melakukan dosa, slogan mereka yang paling terkenal "manusia hanya pada dua kondisi entah beriman atau kafir". Maka muncullah Murjiah sebagai tandingan yang mengatakan seorang fasik keimanannya tetap sempurnah. ${ }^{20}$

\section{Murjiah}

$$
\text { C. Kelompok kelompok }
$$

Wahbah al Zuhailī mengatakan kelompok Murjiah tebagi dua:

1. Murjiah Sunnah : kelompok ini adalah yang meyakini bahwa para pelaku dosa akan dibalas sesuai dengan kadar dosa yang telah dia lakukan, mereka tidak kekal di nereka dan boleh saja Allah mengampuni mereka, sebagaimana firman Allah:" Demikianlah keutamaan yang Allah

${ }^{19}$ Muhammad Abu Zahrah, Tārīkh Al Mazahib Al Islamiayah fi As Siasah wa Al Aqaid wa Tarikh al Mazahib Al Fiqhiyah, h.115.

${ }^{20}$ Abdullah bin Muhammad bin Abdul Aziz An Nasr, Ara' Al Murjiah fi Musonnafati Syekh Al Islam Ibnu taimiyyah, ( Cet. I; Riyadh: Dar At Tauhid li An Nasyr, 1438H/2007). h.94 berikan kepada siapa saja yang Allah kehendaki”

2. Murjiah Bi'dah: Mereka inilah yang disebut dalam banyak istilah Murjiah. ${ }^{21}$

Adapun ulama Al Firaq menyimpulkan beberapa kelompok Murjiah:

1. Murjiah Al Jabariah: mereka adalah pengikut Jaham bin Sofwan, mereka inilah yang berpendapat bahwa keimanan hanya pengetahuan dalam hati, dosa tidak akan pernah mempengaruhi keimanan, dan bahwasanya pengucapan dengan lisan dan amalan soleh bukanlah bagian dari iman.

2. Murjiah Al Qadariyah: mereka adalah kelompok yang dipimpin oleh Gilan Ad Dimisqi yang juga dijuluki Al Gilaniyah.

3. Murjiah Al Khalisah: mereka adalah kelompok yang para ulama masih berselisih penamaan mereka.

4. Murjiah Al Karramiyah: Pengikut Muhammad bin Karram, mereka berpendapat, bahwa keimanan adalah pengucapan dengan lisan, dan pembuktian dengan lisan, dan keimanan tidak membutuhkan persaksian hati.

5. Murjiah Al Khawarij: mereka ini adalah kelompok yang mirip dengan salah satu kelompok Sufi, yang berpemahaman bahwa kami tidak memberikan hukum apapun kepada para pelaku dosa besar. ${ }^{22}$

\section{Argumentasi Murjiah}

\footnotetext{
${ }^{21}$ Muhammad Abu Zahrah, Tāîrkh Al Mażāhib Al Islāmiayah fi Al Siasyah wa Al Aqaid wa Tārīkh al Mażāhib Al Fiqhiyah, h.117.

${ }^{22}$ Galib bin Ali A'waji, Firaq Mua'sirah, Vol. III (Cet. VII; Jeddah: Dar Al A'sriyah, 1430H/2009M), h. 1089.
} 
Kelompok ini dalam menyebarkan pendapat kelompoknya, memiliki beberapa dalil, diantaranya:

1. Dari Al Quran: QS. 3/48:

"إن اله لا يغفر أن يشرك به و يغفر

$$
\text { مادون ذالك لمن يشأل }
$$

Artinya:

"Sesungguhnya Allah tidak akan mengampunkan dosa syikir, dan mengampunkan dosa selainnya. ${ }^{23}$

2. Dari As Sunnah

من مات يشرك بالله شيأ دخل النار

Artinya:

"Barangsiapa yang menyekutukan Allah dan dia meninggal, maka balasannya adalah Neraka ${ }^{24}$

\section{PENUTUP}

Berdasarkan pembahasan di atas, maka dapat disimpulkan beberapa hal berikut:

1. Awal kemunculan berbagai kelompok dalam Islam adalah setelah terbunuhnya Ustman bin Affan.

2. Kelompok yang paling pertama muncul adalah Khawarij, dengan keyakinannya bahwa setiap pelaku dosa besar adalah kafir.

3. Kelompok yang kedua, sebagai tandingan Khawarij yang sangat keras, dan mudah mengkafirkan adalah Murjiah, yang pada awal kemunculannya sebuah upaya untuk tidak ikut campur dalam permasalah yang terjadi antara sahabat, akan tetapi berujung pada kesalahan dan sifat yang berlebihan pada permasalahan keimanan.

4. Konsep Murjiah adalah sekali beriman akan tetap beriman selama-lamanya, walaupun orang

23Terjemahan sendiri tersebut melakukan hal-hal yang bisa mengeluarkannya dari Islam.

5. Setiap kelompok yang muncul begitu mudahnya terpecah, hanya karena permasalahn sepeleh.

6. Setiap kelompok memiliki pemimpin dan prinsip masingmasing.

\section{DAFTAR PUSTAKA}

Al Quran Al Karim

A'waji, Galib bin Ali. Firaq Mua'sirah, Vol. I (Cet. VII; Jeddah: Dar Al A'sriyah, 1430H/2009M).

A'waji, Galib bin Ali. Firaq Mua'sirah, Vol. III (Cet. VII; Jeddah: Dar Al A'sriyah, 1430H/2009M)

Abu Zahrah, Muhammad, Tarikh Al Mazabib Al Islamiayah fi As Siasah wa Al Aqaid wa tarikh al Marabib AlFiqhiyah, (t.Cet, Mesir: Dar Al Fikr Al Arabi, t.t).

Ahmad Jali, Ahmad Muhammad. Dirasatu A'n Al Firaq wa Tarikh Al Muslimin Al Khawarij wa Asy Syiah, (Cet.II; Riyadh, 1408H/1988M).

Al Andalusi, Ibnu Hazm Az Zohiri. Al Fasl fi Al Milal wa Al Abwa wa An Nibal, Vol. IV (Cet. I; maktabah Muhammad Ali Sobih wa Auladuhu, $1347 \mathrm{H})$.

Al Aql, Nasruddin Abdul Karim. Al Khawarij, (Cet. I; Riyadh, $1419 \mathrm{H} / 1998 \mathrm{M})$.

Al Hawali, Safar bin Abdurrahman. Usul al firaq wa Ad Yan wa Al madzabib All fikriayah, (t. cet; Riyadh, 1431H/2010M).

Al Husaini Abu Al Faid, Muhammad bin Muhammad bin Abdurrazak. Taaj Al Arus min Jawabir AlQamus, Vol. V (t.Cet,

${ }^{24}$ Galib bin Ali A'waji, Firaq Mua'sirah, Vol. III. h. 1096 
Website: https://journal.stiba.ac.id

ISSN : 2685-7537 (online) 2338-5251 (Printed)

Ali Muhammad Ash Shalabi. Khawarij dan Syiah dalam Timbangan Ablu Sunnah wal jamaah, ( Cet. I; Jakarta Timur: 2012).

An Nasr, Abdullah bin Muhammad bin Abdul Aziz. Ara' Al Murjiah fi Musonnafati Syekh Al Islam Ibnu taimiyyah, (Cet. I; Riyadh: Dar At Tauhid li An Nasyr, 1438H/2007).

Asy Syiristani, Abu Al Fath Muhammad Abdul Karim Abi Bakar Ahmad. Al Milal wa An Nibal, Vol. I (Muassasah Al halabi wa Asy Syarikah li An Nasyr wa At Tauzi', 1378H1968M).

Az Zāmil, Majid dan Abdurrahman, Mun'im. Al Mujiah Nasyatuba wa Mu'taqadatuba, (t. cet; t.t).

Ibnu Katsir, $\mathrm{Al}$ hafidz. Tafsir $A l$ Quran Al Adrim, Vol. II, (Cet. I; Bairut: darul Khaer, $1410 \mathrm{H})$.

Ibnu Taimiyyah, Ahmad. Majmu' fatawa, Vol. XIII (t.Cet; madinah Al Munawwarah: Majma' Malik Fahad Litibaati Mushaf Asy Syarif, 1425H/2009M).

Mandzur, Ibnu. Lisan Al Arab, Vol XIV, (Cet. I; Bairut: Darun Sodirun, t.t).

Nasution, Harun. Teologi Islam Aliran Aliran Sejarab Analisa perbandingan (Cet. V; UI Press, 2013).

Razak, Abdul dan Anwar Rosihon, Ilmu Kalam, (Cet. IV; Bandung: Cv Pustaka Setia, 2015). 